\title{
Ectopic adrenocortical carcinoma located in the ovary
}

\author{
Farida Chentli', Nadia Terki ${ }^{2}$ and Said Azzoug' \\ 1'Department and Endocrine and Metabolic Diseases, Bab El Oued Teaching Hospital Algiers, Algiers, \\ Algeria and ${ }^{2}$ Department of Pathology, Pierre and Marie Curie Centre, Algiers, Algeria
}

Correspondence should be addressed to F Chentli

Email

chentli.f@gmail.com

\begin{abstract}
Aim: Ovarian corticosteroid-producing tumors are exquisitely rare. Our aim was to describe the first case observed in our practice.

Case history: A 34-year-old female was referred for Cushing's syndrome (CS) occurring in the postpartum period. Clinical examination showed severe CS with diabetes mellitus, hypertension, and a large mass in the right lower abdomen. Biochemistry demonstrated corticotropin (ACTH)-independent CS (cortisol $=1900 \mathrm{ng} / \mathrm{mL}(n=50-250)$, $\mathrm{ACTH}<10 \mathrm{pg} / \mathrm{mL}(n=20-46))$ with estradiol and testosterone overproduction.

Investigations: Abdomen CT scan revealed a $14 \mathrm{~cm}$ right ovarian mass and small adrenal glands. Surgical exploration found the ovarian tumor with hemoperitoneum and enlarged lymph nodes. Histological study confirmed adrenocortical tumor located in the ovary with a Weiss score $>5$, associated with peritoneal and lymph node metastases. Immunohistochemical staining was positive for inhibin- $\alpha$, melan-A, and SF1, demonstrating tissue of adrenal origin. After surgery, plasma glucose level spontaneously returned to normal. However, the patient died on the second post-surgical day due to catastrophic pulmonary embolism.

Conclusion: In this reported case, clinical, hormonal, histological, and immunohistochemical findings confirmed a cortisol and sex hormone-producing ovarian tumor with peritoneal and lymph node metastases, a very rare but
\end{abstract} important condition to recognize.

\section{Introduction}

It is well known that corticotropin (ACTH)-independent Cushing's syndrome (CS) is rarer than the ACTHdependent CS $(1,2)$.

ACTH-independent CS is usually due to benign or malignant tumors located in the adrenal glands $(3,4,5)$. However, in exceptional situations, a tumor located far from the adrenal area may synthesize adrenocortical hormones, mimicking perfectly adrenal secretion.

Ectopic tumors secreting cortisol are so rare that they are not discussed in current reviews on adrenocortical tumors in general and even in adrenocortical carcinomas. Among ectopic neoplasms, ovarian tumors secreting cortisol causing overt CS with metastases are exceptional. To the best of our knowledge, there are six reported cases in English literature: five in human beings $(6,7,8,9)$ and one in a dog (10). Given its rarity, our aim was to describe the first case observed in our practice.

\section{Case report}

A 34-year-old female was referred to our unit for CS with psychiatric signs, diabetes mellitus, and lower limb edema occurring 2 months postpartum. Her medical history was unremarkable. During pregnancy, apart from tiredness, the patient denied having any abnormal symptoms. Her baby was delivered at term by Cesarean section weighing $4.3 \mathrm{~kg}$.

Clinical examination showed severe CS with metabolic and androgenic features including facial plethora, bruises, lower limb edema, severe muscular 
Table 1 Hormonal mean values at diagnosis.

\begin{tabular}{|c|c|c|c|c|c|c|c|c|c|c|}
\hline $\begin{array}{l}\text { Cortisol } \\
\text { (ng/mL) }\end{array}$ & $\begin{array}{c}\text { АСТH } \\
(\mathrm{pg} / \mathrm{mL})\end{array}$ & $\begin{array}{l}\text { DHEA-S } \\
(\mathrm{pg} / \mathrm{mL})\end{array}$ & $\begin{array}{l}\text { 17-OHP } \\
\text { (nmol/L) }\end{array}$ & $\begin{array}{c}\text { TT } \\
(\mathrm{ng} / \mathrm{mL})\end{array}$ & $\begin{array}{c}\mathbf{E}_{\mathbf{2}} \\
(\mathrm{pg} / \mathrm{mL})\end{array}$ & $\begin{array}{c}\text { FSH } \\
(\mathrm{U} / \mathrm{mL})\end{array}$ & $\begin{array}{c}\text { LH } \\
(\mathrm{U} / \mathrm{mL})\end{array}$ & $\begin{array}{c}\text { PRL } \\
(\mathrm{ng} / \mathrm{mL})\end{array}$ & $\begin{array}{c}\text { TSH } \\
(\mu \mathrm{U} / \mathrm{mL})\end{array}$ & $\begin{array}{c}\text { FT4 } \\
(\mathrm{pmol} / \mathrm{L})\end{array}$ \\
\hline $\begin{array}{l}\text { Before DXM } 1990 \\
\text { After } 2 \mathrm{mg} \text { DXM = } 1840 \\
\text { After } 8 \mathrm{mg}=848 \\
\text { Reference values }\end{array}$ & $<10$ & 548 & 28.8 & 4.5 & 124 & 0.16 & 0.7 & 13 & 0.58 & 13.8 \\
\hline $50-250$ & $20-46$ & $50-580$ & $0.3-3$ & $0.1-1.2$ & $<50$ & $2.8-11$ & $1.1-11$ & $3-20$ & $0.2-4$ & $9-20$ \\
\hline
\end{tabular}

17-OHP, 17-hydroxyprogesterone; ACTH, adrenocorticotropin; DHEA-S, dehydroepiandrosterone sulfate; DXM, dexamethasone; $\mathrm{E}_{2}$, estradiol; FSH, follicle-stimulating hormone; $\mathrm{FT}_{4}$, free thyroxin; $\mathrm{LH}$, luteinizing hormone; PRL, prolactin; $\mathrm{TSH}$, thyroid-stimulating hormone; TT, total testosterone.

atrophy, and hirsutism. She weighed $58 \mathrm{~kg}$, height $159 \mathrm{~cm}$ $\left(\mathrm{BMI}=27.5 \mathrm{~kg} / \mathrm{m}^{2}\right)$, and had an increased abdominal girth of $102 \mathrm{~cm}$. Blood pressures varied between $150 / 90$ and $170 / 100 \mathrm{mmHg}$. There was a large palpable mass in the right pelvic area. Galactorrhea and skin hyperpigmentation were absent. Hormonal parameters, done through chemiluminescence, confirmed an ACTHindependent CS (Table 1) with high sex hormones (estradiol and testosterone) and 17-OH progesterone. The very high serum cortisol failed to be suppressed by both 2 and $8 \mathrm{mg}$ dexamethasone. Other evaluated hormonal parameters were within the normal range, except for low FSH and LH levels.

Routine analyses showed normal liver and renal function; however, hyperglycemia, mild dyslipidemia, hypokalemia, and a normocytic hypochromic anemia were present (Table 2).

Abdomen ultrasound did not show any adrenal masses. CT scan showed small adrenal glands and a $14 \mathrm{~cm}$ heterogeneous tumor in the right pelvic area (Fig. 1) with ascites.

Chest $\mathrm{x}$-ray was unremarkable and echocardiography showed an increase in septal size related to systemic hypertension. Work up for distant metastases was negative.

Table 2 Routine analyses.

\begin{tabular}{|c|c|c|}
\hline Plasma parameters & Patient's values & Normal values \\
\hline Glucose & 267 & $70-100 \mathrm{mg} / \mathrm{dL}$ \\
\hline Triglycerides & 1.61 & $\leq 1.5 \mathrm{~g} / \mathrm{L}$ \\
\hline HDL cholesterol & 0.36 & $\geq 0.50$ \\
\hline Total cholesterol & 1.95 & $\leq 2 \mathrm{~g} / \mathrm{L}$ \\
\hline Sodium & 144 & $135-145 \mathrm{meq} / \mathrm{L}$ \\
\hline Potassium & 2.4 & $3.5-5 \mathrm{meq} / \mathrm{L}$ \\
\hline Hemoglobin & 6.8 & $11-14 \mathrm{~g} / \mathrm{dL}$ \\
\hline Hematocrit & 21 & $35-45 \%$ \\
\hline MCV & 94 & 80-99fL \\
\hline $\mathrm{MCHC}$ & 31 & $33-37 \mathrm{~g} / \mathrm{dL}$ \\
\hline
\end{tabular}

MCHC, mean cell hemoglobin concentration; MCV, mean corpuscular volume or mean cell volume.
In this patient with rapid evolution, lack of skin hyperpigmentation and low plasma ACTH levels suggested ACTH-independent CS. As both adrenals were small in size with no masses, ectopic glucocorticoids production by the large pelvic tumor was suspected.

Tumor markers were normal (CEA: $1.09 \mathrm{ng} / \mathrm{mL}$ $(n \leq 10)$, AFP: $3.8 \mathrm{IU} / \mathrm{mL}(n \leq 10)$, and beta HCG: negative), except for $\mathrm{Ca} 125$, which was slightly increased= $52.5 \mathrm{IU} / \mathrm{mL}(n=0.1-35)$.

At surgery, a malignant process was encountered by a large friable ovarian mass with abnormal lymph nodes and $400 \mathrm{~mL}$ hemoperitoneum. The patient underwent total resection with immediate normalization of plasma glucose without any treatment, apart from hydrocortisone given for adrenocortical substitution. On the second postoperative day, the patient died of acute pulmonary embolism.

Macroscopic examination showed a brown lobulated mass measuring $14.5 \times 13.7 \mathrm{~cm}$ located in the ovary. Cut sections were heterogeneous with numerous hemorrhage and large necrotic areas.

Histological examination showed an encapsulated tumor within the ovary, but with some areas that had breached the capsule (Fig. 2).

The pathological tissue composed of cells arranged in an endocrine and trabecular aspect with vascular embolism and large necrotic areas, with nests of cells similar in appearance to different layers of adrenocortical gland (Fig. 2). A large part of tumor cells was pleomorphic: some were polygonal, others had a round shape. Their cytoplasm was finely granular. The nuclei were vesicular and hyperchromatic with abnormal mitotic figures. Spongiocytic aspects, composed of lipidladen cells (similar to those of the glomerular zone), with prominent and monstrous nuclei were also observed. The Weiss score was $>5$.

Immunohistochemical staining was positive for inhibin- $\alpha$, melan-A, and steroidogenic factor 1 (SF1) (Fig. 3). The positivity was discrete for synaptophysin and 

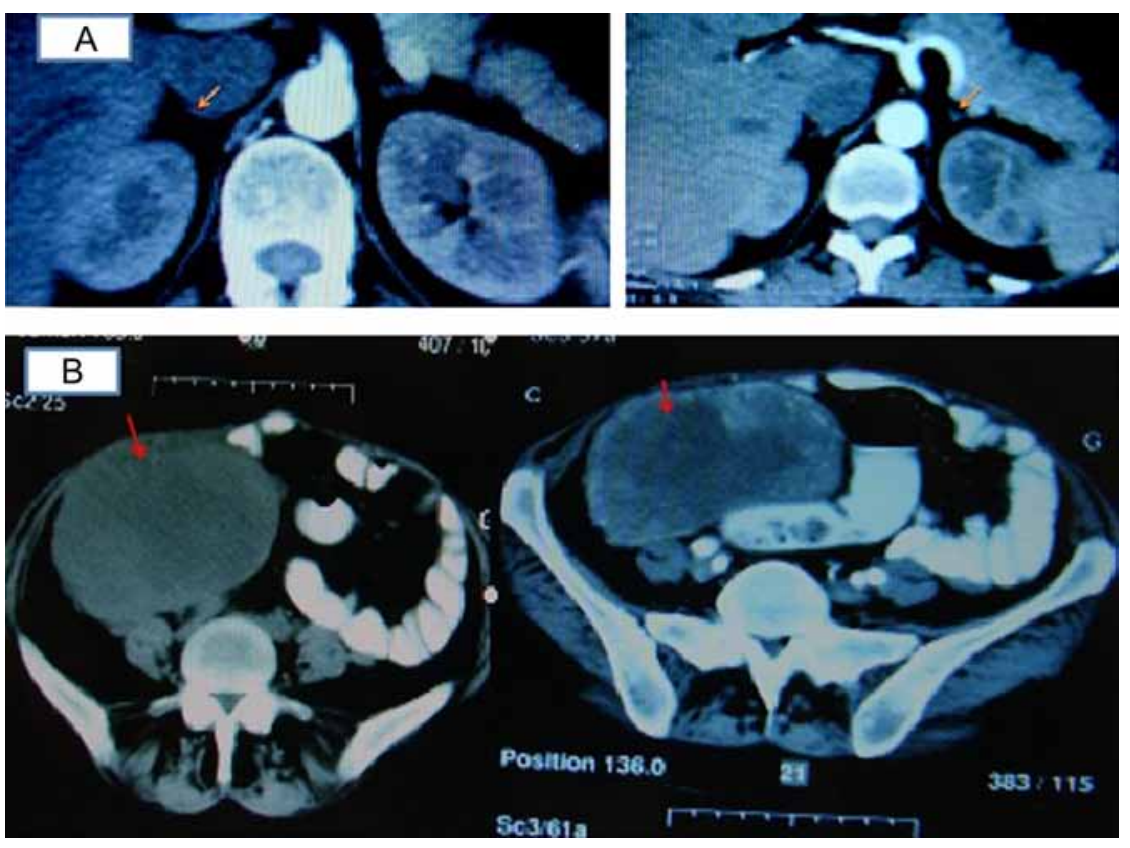

\section{Figure 1}

(A) Abdomen CT scan showing two small adrenals (orange arrows). (B) Pelvic CT scan showing a large heterogeneous tumor reaching the parietal wall (red arrows). A full colour version of this figure is available at http://dx.doi.org/10.1530/EJE-16-0224. negative for ACTH, CD 99 (cluster of differentiation 99), cytokeratin AE1/AE3, and calretinin.

Lymph node examination demonstrated that one out of three nodes contained abnormal cells similar to those observed in the ovarian tumor. The peritoneal fluid contained pathological cells.

All these features classified the ovarian tumor as ectopic and poorly differentiated (high grade of malignancy) adrenocortical tumor responsible for ACTHindependent CS. The tumor was considered malignant because of lymph node and peritoneal metastases.

\section{Discussion}

Primary or eutopic adrenocortical carcinomas are very rare tumors with an incidence of $0.5-2$ per million per year (11). Due to their poor prognosis, they are considered the second most aggressive endocrine malignancy behind anaplastic thyroid cancers.
Adrenocortical neoplasms arising in ectopic locations are extremely rare, and those secreting cortisol are even rarer. Their frequency, incidence and follow-up are totally unknown.

Ovarian localization seems to be exceptional, as to the best of our knowledge; fewer than ten cases have been reported so far in the world literature. Their main characteristics and follow-up are summarized in Table 3.

The first well-documented ovarian carcinoma producing cortisol was reported by Marieb in 1987 (6). On the pathological point, this type of tumor was classified as a lipoid cell tumor of the ovary, as ovarian lipoid tumors are commonly associated with androgenic and estrogenic effects and less frequently with other endocrinological abnormalities (8).

In our case, there is no doubt about the overproduction of cortisol by the tumor located in the ovary, as ACTH was very low, the adrenal glands were small and tumor free, and with ectopic adrenal tissue within the ovary. The ectopic adrenal tissue was

\section{Figure 2}

(A) Tumor tissue surrounded by a layer of normal ovarian tissue. Notice the numerous vascular embolisms. (B) High cellular density with granular, hyperchromatic and giant nuclei. (C) Abnormal mitoses. A full colour version of this figure is available at http://dx.doi. org/10.1530/EJE-16-0224. 


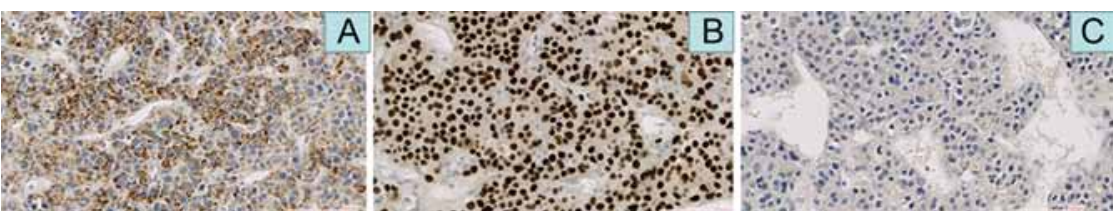

Figure 3

Immunohistochemical staining showing positivity to melan-A (A) and SF1 (B), and negativity to ACTH (C). A full colour version of this figure is available at http:// dx.doi.org/10.1530/EJE-16-0224.

confirmed by immunostaining positivity to inhibin- $\alpha$, melan-A, SF1, and synaptophysin. Although distant metastases were absent, the large size, histopathological characteristics, and presence of lymph node and peritoneal metastases defined a malignant process. The negativity of tumor markers does not argue at all against malignancy, especially in tumors secreting cortisol, as glucocorticoid excess inhibits tumor markers (12).

Overt or subclinical CS (13) due to ovarian tumor is an exceptional phenomenon. Only two types of ovarian tumors may be responsible for CS: the first group secretes ACTH or an ACTH-like substance generating paraneoplastic CS, where both adrenals are large as stimulated by an ectopic ACTH, and the second group, which is uncommon, synthesizes some or most adrenocortical steroids that inhibit pituitary corticotropin hormone. In this situation, the adrenal glands are usually atrophic and non-functioning as demonstrated by postmortem studies (Table 3).

Most ovarian tumors secreting adrenal hormones reported in the literature are considered benign (14) probably because histological examination is generally unable to give the certainty of malignancy, or because they are published after a short follow-up period.

Searching Pub Med and Google scholar, we found only six malignant intra-ovarian tumors secreting cortisol with proven metastases. Five were described in humans $(6,7,8,9)$, and one in a dog (10). Our case is the sixth human case.

The mechanism of adrenal tumors arising from the ovary is still debated. One theory is that these tumors originate from transformation of the adrenocortical embryonic remnants that broke off during adrenal migration or descent with gonadal cells (15). For the second theory, ectopic adrenal adenomas/carcinomas may result from mutation of ovarian tissue and its steroid enzymes and/or acquisition of aberrant receptors (16) that are stimulated not by ACTH but by LH and/or HCG, especially during pregnancy (which may be the case in our patient). This pathological situation allows the ovary to synthesize adrenal hormones.

For the first theory, adrenal embryonic remnants are well known, as they were demonstrated for the first time in 1740 by Schelter and then confirmed by Marchand in 1843 (17). Necropsy studies revealed that ectopic adrenal tissue is frequently found in newborns and children, but it is less common in adults. Adrenal aberrant tissue can be situated anywhere, especially in the pathway of the genital tract migration: celiac trunk, ovaries, testes, spermatic cord, and kidneys (18). Although very rare, normal, hyperplastic, or tumorous adrenal tissue has been observed in unusual sites such as pulmonary area, liver, stomach, brain, and spinal cord (19).

Tumors arising from adrenal remnants are usually scarce. They are often benign (20) and nonfunctioning. They are discovered incidentally, or after surgery for inguinal hernia (21), pathology of the testis or spermatic cord (22), or at autopsy studies. However on occasion, these tumors may be functional $(13,14$, 20) and produce glucocorticoids, androgens (19), or mineralocorticoids (23).

Functioning, benign or malignant, ectopic adrenocortical tumors may also arise from the kidneys (24) or near it $(17,18)$, near the adrenal gland, in the retro-hepatic space (25), in the testis (26), placenta (27), large intestine (28), or in the ovary $(7,8,9,10,13)$.

The prognosis of ectopic ovarian tumors secreting cortisol seems to be worse in comparison with eutopic tumors, with mean survival of 8 months (0-18) for the six ovarian tumors secreting cortisol (Table 3) vs 31.5 months for eutopic adrenal carcinomas reported by Bilimoria et al. (29). When the tumor appears and/ or overgrows during pregnancy, as in the reported case, the prognosis is the worst. Rapid progression during pregnancy or in the early postpartum period can be explained by an increased sensitivity of ovarian receptors to LH, HCG, or to aberrant, illicit, or inappropriate membrane hormone receptors as postulated for eutopic adrenocortical tumors (16).

The treatment of ectopic adrenocortical carcinoma does not differ from that of eutopic tumors. Surgery is the cornerstone, but mitotane and ketoconazole alone or with metyrapone (30) can be useful as in eutopic disease. Classical or targeted chemotherapy may also be used. However, the results are generally poor because of the 


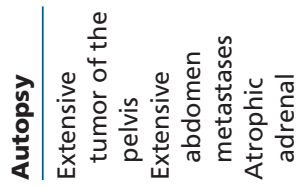

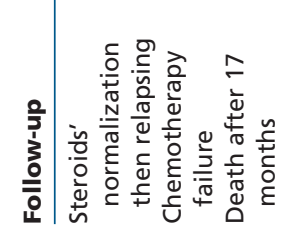

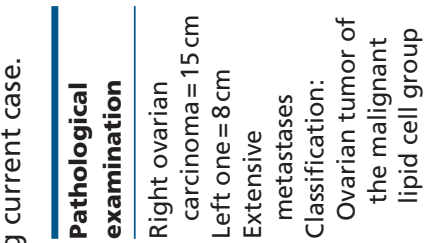

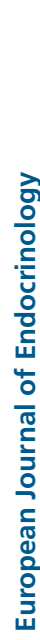

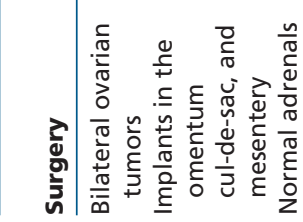

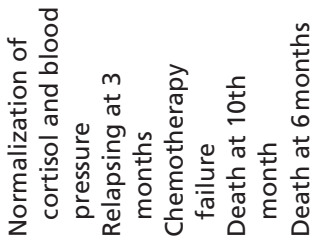

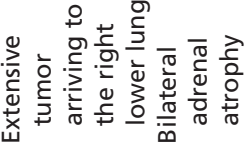
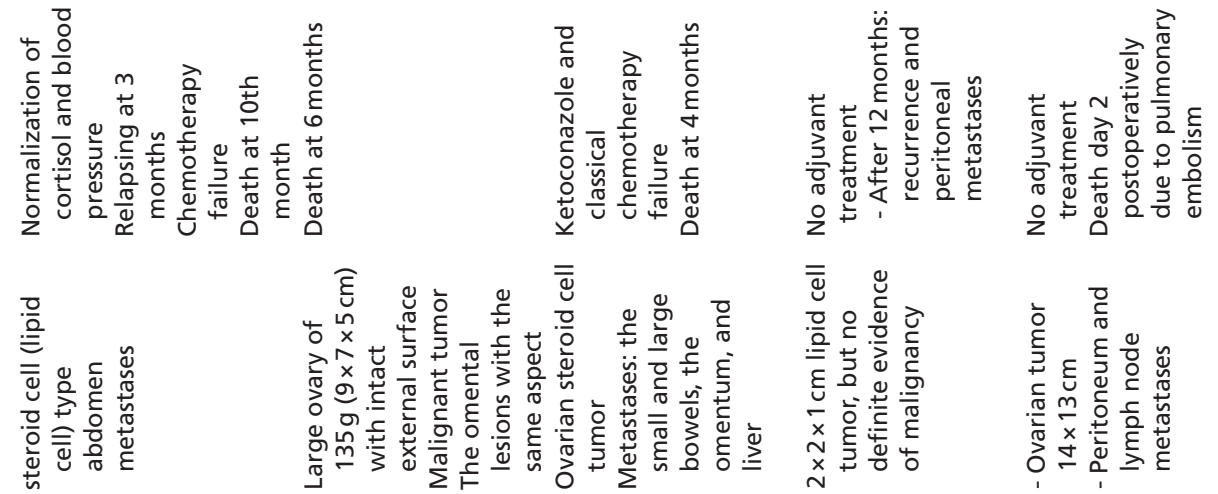

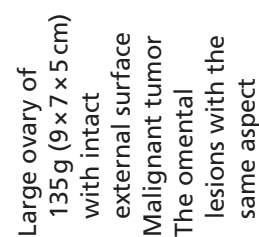

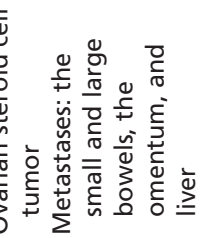

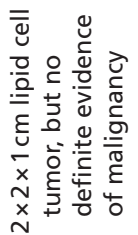
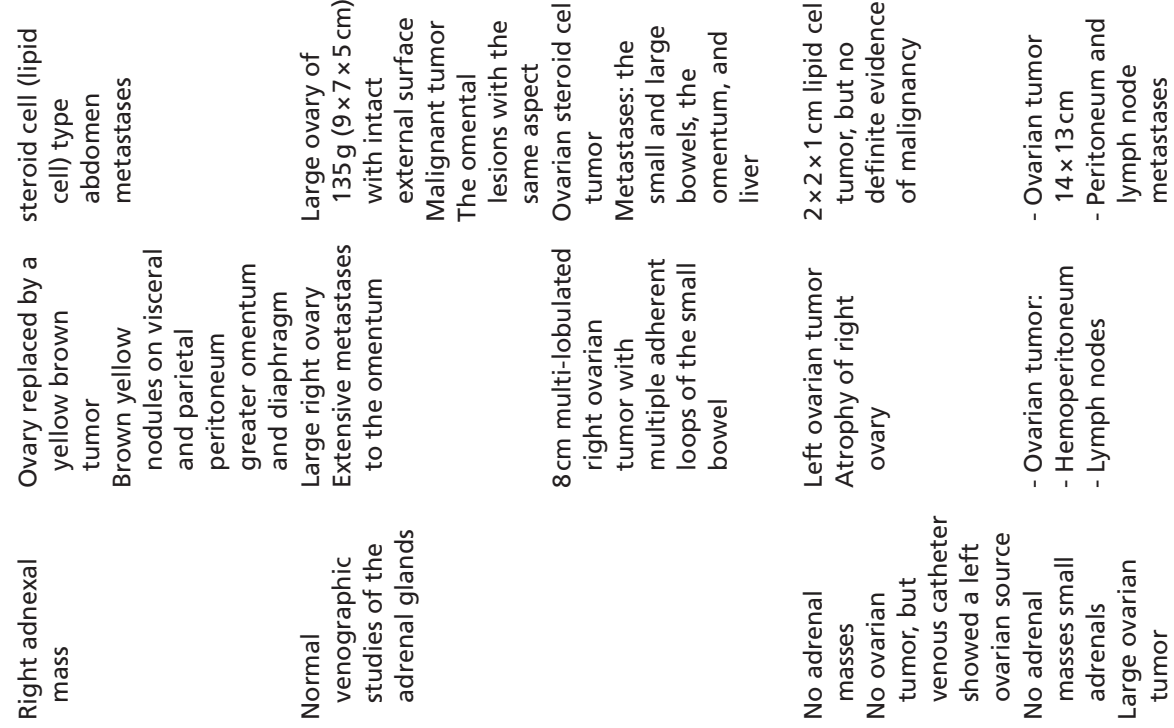

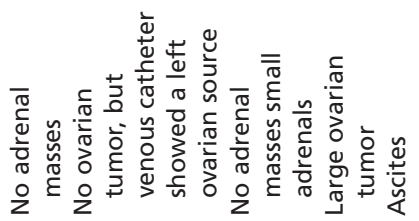

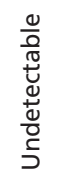

$\frac{\bar{c}}{\sum^{\bar{O}}}$

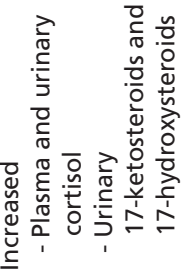

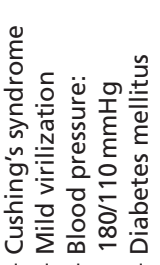

$\stackrel{\infty}{+}$

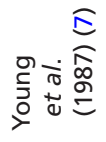

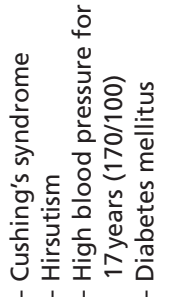

กิ

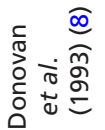

है

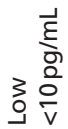

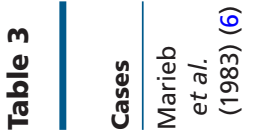

章

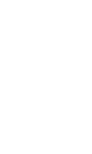


aggressive and poorly differentiated character of ectopic adrenocortical tumors.

The prognosis is poor as death may be caused by metabolic disorders such as severe hypokalemia and ketoacidosis. However, the most threatening causes are metastatic disease and thromboembolism. The later occurs frequently in CS in general (31), and especially in adrenocortical tumors because of the hypercoagulable state due to an increase in pro-coagulant factors (32).

\section{Conclusion}

In our observation, ACTH-independent Cushing's syndrome with small adrenals was suggestive of an ectopic tumor producing glucocorticoids and sex hormones. Abdomen CT scan and surgical exploration revealed an ovarian primary mass with metastatic spread. Histological, immunohistochemical staining, and normalization of glucose metabolism just after ovarian tumor resection support glucocorticoids and other hormone secretion from the ovary.

Although this phenomenon is exceptional, gynecologists, endocrinologists, and pathologists should be aware that ectopic adrenocortical tumors might arise in ovaries. Morphological features combined with immunephenotype (melan-A, inhibin- $\alpha$, and synaptophysin) and ultrastructural findings are essential in ruling out other forms of ovarian tumors. High mortality is associated with this disease.

\section{Declaration of interest}

The authors declare that there is no conflict of interest that would prejudice the impartiality of this scientific work.

\section{Funding}

This research did not receive any specific grant from any funding agency in the public, commercial or profit sector.

\section{Acknowledgements}

The authors are grateful to Dr Carmela Caputo for language editing. The authors would like to thank Drs Frederic Tissier, Anne Audebourg and Brigitte Radenen, Department of Pathology, Cochin Hospital and Descartes University (France) for the immunohistochemical study, Drs Khireddine Osmani and Malik Benamara for their help concerning some references, and Dr Yesli Fatma for histological pictures.

\section{References}

1 Lahera Vargas M \& da Costa CV. Prevalence, etiology and clinical findings of Cushing's syndrome. Endocrinología y Nutrición 200956 32-39. (doi:10.1016/S1575-0922(09)70191-3)
2 Bhansali A, Walia R, Rana SS, Dutta P, Radotra BD, Khandelwal N \& Bhadada SK. Ectopic Cushing's syndrome: experience from a tertiary care centre. Indian Journal of Medical Research 2009129 33-41.

3 Terzolo M, Bovio S, Pia A, Reimondo G \& Angeli A. Management of adrenal incidentaloma. Best Practice \& Research: Clinical Endocrinology \& Metabolism 200923 233-243. (doi:10.1016/j. beem.2009.04.001)

4 Pollack RP \& Brett E. ACTH-independent Cushing's syndrome presenting during pregnancy. Endocrine Practice 20096 1-11.

5 Louiset E, Gobet F, Libé R, Horvath A, Renouf S, Cariou J Rothenbuhler A, Bertherat J, Clauser E, Grise P et al. ACTHindependent Cushing's syndrome with bilateral micronodular adrenal hyperplasia and ectopic adrenocortical adenoma. Journal of Clinical Endocrinology and Metabolism 201095 18-24. (doi:10.1210/ jc.2009-0881)

6 Marieb NJ, Spangler S, Kashgarian M, Heimann A, Schwartz ML $\&$ Schwartz PE. Cushing's syndrome secondary to ectopic cortisol production by an ovarian carcinoma. Journal of Clinical Endocrinology and Metabolism 198357 737-740. (doi:10.1210/jcem-57-4-737)

7 Young RH \& Scully RE. Ovarian steroid cell tumors associated with Cushing's syndrome: a report of three cases. International Journal of Gynecological Pathology 19876 40-48. (doi:10.1097/00004347198703000-00005)

8 Donovan JT, Otis CN, Powell JL \& Cathcart HK. Cushing's syndrome secondary to malignant lipoid cell tumor of the ovary. Gynecologic Oncology 199350 249-253. (doi:10.1006/gyno.1993.1202)

9 Elhadd TA, Connolly V, Cruickshank D \& Kelly WF. An ovarian lipid cell tumor causing virilization and Cushing's syndrome. Clinical Endocrinology 199644 723-725. (doi:10.1046/j.13652265.1996.693515.x)

10 Yamini B, Vandenbrink PL \& Refsal KR. Ovarian steroid cell tumor resembling luteoma associated with hyperadrenocorticism (Cushing's disease) in a dog. Veterinary Pathology 199734 57-60. (doi:10.1177/ 030098589703400112)

11 Yokoyama H, Adachi T, Tsubouchi K, Tanaka M \& Sasano H. Non-functioning adrenocortical carcinoma arising in an adrenal rest: immunohistochemical study of an adult patient. Tohoku Journal of Experimental Medicine 2013229 267-270. (doi:10.1620/ tjem.229.267)

12 Karlan BY, Amin W, Casper SE \& Littlefield BA. Hormonal regulation of CA125 tumor marker expression in human ovarian carcinoma cells: inhibition by glucocorticoids. Cancer Research 198848 3502-3506.

13 Diab DL, Faiman C, Siperstein AE, Grossman WF, Rabinowitz LO \& Hamrahian AH. Virilizing ovarian Leydig cell tumor in a woman with subclinical Cushing syndrome. Endocrine Practice 200814 358-561. (doi:10.4158/EP.14.3.358)

14 Adeyemi SD, Grange AO, Giwa-Osagie OF \& Elesha SO. Adrenal rest tumour of the ovary associated with isosexual precocious pseudopuberty and Cuhingoid features. European Journal of Pediatrics 1986 145 236-238. (doi:10.1007/BF00446077)

15 Vassiliadi D \& Tsagarakis S. Unusual causes of Cushing's syndrome. Arquivos Brasileiros de Endocrinologia \& Metabologia $2007 \mathbf{5 1}$ 1245-1252. (doi:10.1007/BF00446077)

16 Lacroix A, Ndiaye N, Tremblay J \& Hamet P. Ectopic and abnormal hormone receptors in adrenal Cushing's syndrome. Endocrine Reviews 200122 75-110. (doi:10.1210/er.22.1.75)

17 Leibowitz J, Pertsemlides \& Gabrilove JL. Recurrent Cushing's syndrome due to recurrent adrenocortical tumor fragmentation or tumor ectopic adrenal tissue? Journal of Clinical Endocrinology and Metabolism 199883 3786-3789. (doi:10.1210/jcem.83. 11.5260)

18 Ayala AR, Basaria S, Udelsman R, Westra WH \& Wand GS. Corticotrophin independent Cushing's syndrome caused by an ectopic adrenal adenoma. Journal of Clinical 
Endocrinology and Metabolism 200085 2903-2906. (doi:10.1210/ jc.85.8.2903)

19 Skórka A, Moszczyńska E, Kot K, Roszkowski M, Jurkiewicz E, Grajkowska W, Pronicki M, Pilecki O \& Szalecki M. Ectopic virilising adrenocortical tumour in the spinal region in an 8 year-old boy: a case report and review of the literature. Italian Journal of Pediatrics 201541 62. (doi:10.1186/s13052-0150169-8)

20 Cariou J, Grise P, Caremel R, De Fourmestraux A \& Albouy B. Treatment by iterative endoscopic retroperitoneal adrenalectomy of an ectopic adrenal adenoma revealed by Cushing's syndrome. Progrès en Urologie 200818 68-70. (doi:10.1016/ j.purol.2007.12.004)

21 Vuong P, Bazza F, Houssa-Vuong S, Baviera E \& Janzen J. The ectopic adrenal tissue in an inguinal hernia. Schweizerisches Medizin-Forum $20066327-328$.

22 Chacar H, Gebran S, Hajje MJ, Bedoyan Z \& Jalbout N. Aberrant adrenocortical tissue along the spermatic cord in a 2 months old boy. Revue Medicale Libanaise 200315 121-122.

23 Todesco S, Terribile V, Borsatti A \& Mantero F. Primary aldosteronism due to a malignant ovarian tumor. Journal of Clinical Endocrinology and Metabolism 197541 809-189. (doi:10.1210/ jcem-41-5-809)

24 Baydar D \& Aydin O. Confusing cases: clear cell but not renal cell lesions in kidney. Pathology International 200858 713-717. (doi:10.1111/pin.2008.58.issue-11)

25 Ney RL, Hammon W, Wright L, Davis WW, Acker J \& Barter FC. Studies in a patient with an ectopic adrenal tumor. Journal of Clinical
Endocrinology and Metabolism 196626 299-304. (doi:10.1210/ jcem-26-3-299)

26 Jain SH, Sadow PM, Nosé V \& Dluhy RG. A patient with ectopic cortisol production derived from malignant testicular masses. Nature Clinical Practice Endocrinology \& Metabolism 20084 695-700. (doi:10.1038/ncpendmet0985)

27 Labarrere CA, Caccalo D, Telenta M, Althabe O \& Gutman R. A nodule of adrenocortical tissue within a human placenta: light microscopic and immunocytochemical findings. Placenta 19845 139-143. (doi:10.1016/S0143-4004(84)80057-0)

28 Bal A, Adhya AK \& Manhadjar JK. Ectopic adrenal rest in the wall of the large intestine. Indian Journal of Pathology and Microbiology 2009 52 130-131. (doi:10.4103/0377-4929.44980)

29 Bilimoria KY, Shen WT, Elaraj D, Bentrem DJ, Winchester DJ, Kebebew E \& Sturgeon C. Adrenocortical carcinoma in the United States: treatment utilization and prognostic factors. Cancer 2008113 3130-3136. (doi:10.1002/cncr.23886)

30 Corcuff JB, Young J, Masquefa-Giraud P, Chanson P, Baudin E \& Tabarin A. Rapid control of severe neoplastic hypercortisolism with metyrapone and ketoconazole. European Journal of Endocrinology 2015 172 473-781. (doi:10.1530/EJE-14-0913)

31 Van der Pas R, Leebeek FW, Hofland LJ, de Herder WW \& Feelders RA. Hypercoagulability in Cushing's syndrome: prevalence, pathogenesis and treatment. Clinical Endocrinology 201378 481-488. (doi:10.1111/ cen.2013.78.issue-4)

32 Aung SY, Parentea P \& McKendricka J. Pulmonary embolism as an initial presentation of adrenocortical carcinoma. World Journal of Oncology 20145 149-152. (doi:10.5306/wjco.v5.i2.149)

Received 14 March 2016

Revised version received 2 July 2016

Accepted 7 July 2016 